\title{
Latin America's Racial Caste System: Salient Marketing Implications
}

Rutilio Martinez, University of Northern Colorado, USA Vish Iyer, University of Northern Colorado, USA

\begin{abstract}
Latin American societies are structured in a fuzzy racial caste system. Whites are at the top. Next are individuals of mixed European and Indian or mixed European and African ancestry, the Mestizos and the Mulattos, respectively. At the bottom are the Indians and the blacks. Integral to this system is an overt preference for European appearance and, among many whites, the firm conviction that the dark-skinned are racially inferior. This results in exclusive use of models of European appearance in publicity channels, higher prices of luxury goods, and the perception that Latin American products are of poor quality.
\end{abstract}

Keywords: caste, European appearance, Mestizo, Mulatto, low income, dark-skinned

\section{INTRODUCTION}

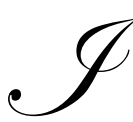

n colonial times the Latin American societies were organized in a rigid, racially determined, caste system. The upper two castes included whites only. Below these two came the castes formed by individuals of mixed European and Indian ancestry, the Mestizos. Next in the pecking order were those of mixed European and Africa ancestry, the Mulattos. In the lowest castes were the Indians and the blacks. From the perspective of the whites, this hierarchy was more than a mere expression of colonial power. It was also an expression of the natural order regarding intelligence and beauty among the races.

Nowadays, some 185 years after most of the Latin American nations obtained their independence, none of the Latin governments consider race to be an issue. All of these governments are firmly convinced that the racial caste system of colonial times has totally disappeared. This firmly held conviction is, however, not shared by academics and ordinary citizens who have noticed the distinct racial stratification of the Latin American societies. For these dissenters, the prevailing racial economic hierarchy and the, easily uncovered, attitudes that consider the dark-skinned unattractive and inferior clearly indicate that the racial caste system continues to operate.

Today's racial caste system is, of course, not nearly as rigid as it was in colonial times. But the fact that it has survived 185 years of social, economic and political advances implies that this system is deeply embedded in the Latin societies. Hence, it must have relevant social, economic and political effects. This paper, however, only discusses the effects that this racial system has on the marketing mix. Due to the fact that the racial reality in Latin America is contentious, the next section briefly discusses events and arguments that highlight the continued presence of the racial caste system in the Latin American countries.

The remainder of this paper is organized as follows: Section 3 discusses the effects that the racial caste system has on publicity channels; Section 4 describes salient implications that this system has on the other elements of the marketing mix; namely price, product and place; Section 5 discusses racially motivated issues that darkskinned, non Latin American executives may face when assigned to a Latin American nation; in Section 6 it is argued that the free market reforms and demographic changes that are taking place in most Latin nations are not undermining the relevance of the racial caste system, but they are likely to continue expanding the demand for all kinds of goods, including high income goods. Section 7 contains conclusions. 


\section{THE RESILIENT RACIAL CASTE SYSTEM}

As mentioned in the introduction, the Latin American governments are convinced that race and racial appearance are not an issue in their societies. This conviction is also held by many Latin Americans. Several facts support this firmly held conviction. Among them: the glorification of the Indian past in countries with a significant Indian population like Guatemala, Mexico and Peru; the complete absence of virulent racial animosity; the election as president of a Mulatto, in Venezuela, and of an Indian, in Bolivia; the visible participation of dark-skinned individuals in the congresses of most Latin nations; the emergence of a large consumer class where most consumers are dark skinned, like in Mexico; and most importantly, the absence of any laws outlawing racial discrimination which implies that this type of discrimination is non-existent.

These facts only show one side, the benign side, of the racial reality of Latin America. This reality also has an ugly side. Crucial components of this ugly side are the racist attitudes held by many whites and racially mixed individuals who pass as whites. These attitudes, although officially non-existent, have been present in the white segments of the Latin American societies for as long as these societies have existed.

For most Latin nations, their first three or four decades of independence were afflicted by economic stagnation and political violence. This began to change in the middle of the nineteenth century. From that time until the early 1930s, most Latin nations experienced several decades of sustained economic growth and political stability [Bulmer-Thomas, 2003, pp. 9-17]. During these decades the oligarchies and the governments of the Latin nations did not implement policies that would have eroded the racial caste system inherited from colonial times. On the contrary, they openly adopted the racial theories that prevailed in the USA and Europe. These theories postulated that only the white man was capable of developing a country because Indians, blacks, and individuals of mixed race were naturally inferior. Accordingly, in Argentina, Indians were exterminated to make room for European immigrants; while in Venezuela, Brazil, Cuba, Guatemala, Mexico and other Latin nations, governments adopted policies that promoted the advancement of whites, but not that of the dark-skinned. Among these were: giving the best agricultural lands to whites, prohibiting the entrance of non-whites, but favoring the immigration of Europeans, and maintaining through violent means, the level of wages at the survival level [Bulmer-Thomas, 2003, pp.86-87; Graham, 1990, pp. 1-4; Hely,1990, pp.37-42; Herring, 1968, p. 329; Knight, 1990, pp.78-80; Stavenhagen, 1994, p. 334; and Skidmore, 1990, pp. 7-12]

By the 1930s the governments of the Latin nations had discarded the racist ideologies that they had adopted in previous decades. Since then, the Latin societies have become predominantly urban, their literacy rates have surpassed the $90 \%$ level, they have formed large working classes, and practically all of them have elected democratic governments. Despite this economic, social and political progress, racist attitudes have continued to crop up.

At the end of the 1960s, in a study of Mexican entrepreneurs done by the OECD, the main entrepreneurs of Mexico, all of whom were of exclusive European ancestry, openly stated their belief that Indians and Mestizos were inferior [Derossi, 1971, p. 149]. Later, in the 1990s, the Argentineans continued to insist that they were Europeans, hence, inherently superior to the Indians, blacks and racially mixed Latin Americans [The Economist, 1994]; while the conviction that the dark-skinned were indolent and unattractive was found to be very commonly held by members of the upper classes of several Latin nations [Nevaer, 1995, pp.101-105; Wagley, 1994, p.25; and Wright, 1990, pp. 99-129]. More recently, in 2005, Carlos Mosnivais, one of Mexico's most respected intellectuals published an essay where he argued that, whether Mexicans accept it or not, most whites and individuals who pass as whites continue to despise the-dark skinned [Monsivais, 2005].

These attitudes, although dismissed as irrelevant by many Latin Americans, influence the Latin societies. Such influence is visible in the distribution of wealth. In the Latin nations the oligarchy is exclusively white. Whites also dominate the class that, in terms of wealth, is right below the oligarchy. Next in the economic pecking order come the individuals of mixed race, with those who have predominantly European appearance normally ahead of those who have predominantly African or Indian appearance. At the bottom are the blacks and the Indians [Nevaer, 1995, p. 102; Patrinos, H., \& Hall, G., 2005, pp. 3-5; Skidmore, 1990, p. 28; Stavengahen, 1994, p.33; and Wagley, 
1994, pp.22-25]. This economic pecking order would be justifiable in Argentina, Costa Rica, Chile and Uruguay, where whites are the majority [CIA, 2008]. In the countries where Indians, Mestizos or Mulattos are the majority, the direct correlation between European appearance and economic position suggests that the white minority has the power to put in practice their attitudes regarding race and racial appearance. Hence, it can be concluded that the racial caste system, although not nearly as rigid as in colonial times, continues to operate throughout Latin America.

\section{IMPLICATIONS OF THE RACIAL CASTE STRUCTURE ON ADVERTISEMENT AND PROMOTION}

The most visible marketing effect of the racial caste system is on promotion and publicity. From Mexico to Argentina there is an unwritten rule that the models used in T.V. and internet commercials as well as in printed ads must be of European appearance. This rule applies to the publicity and advertisement of all kind goods and services, including unsophisticated goods and services such as: diapers, cubes of chicken broth, sodas, beer, fast food restaurants, hotels for the working classes, cigarettes and cheap clothing.

If the goods or services are supposed to be quite sophisticated, elegant and expensive, the models for the T.V. commercials and printed ads for these goods and services tend to be of northern European appearance. That is, in the commercials and printed ads of the most sophisticated goods and services, models whose appearance is Scandinavian are preferred to models whose appearance is Mediterranean.

There are, however, three exceptions to the rule of using models of European appearance exclusively. One is in Brazil, the second one is in the area of celebrity marketing, and the third exception corresponds to the publicity and advertisement of messages of social interest.

In Brazil, since the late 1990s black and Mulatto models have appeared in T.V. and commercials and printed ads. This has been result, according to those who have studied this trend, of the noticeable growth in the income of blacks and Mulattos [Jordan, 2000]. This contrasts with what has happened in other Latin countries, like Colombia, Mexico and Venezuela, where there is a growing number of affluent and relatively affluent dark-skinned consumers In these three nations internet and T.V. commercials and printed ads continue to exclude models of Indian, Mestizo, black and Mulatto appearance. This contrast may be explained by the fact that Brazil is the only Latin nation where the issue of race has been openly discussed, and hence, the only Latin country where society recognizes that in business, economics and politics, race and racial appearance matter [Skidmore, 1990, pp. 27-28].

In the area of celebrity marketing, the exception to the rule of using models of European appearance applies in all the Latin nations. From Mexico to Argentina, famous black, Mulatto, and Mestizo athletes appear in commercials and printed ads. These are very accomplished soccer players who play in Europe, or very accomplished baseball and basketball players who play in the major leagues or in the NBA in the USA. Playing in Europe or in the USA, gives these famous professional athletes an image of sophistication and success that overcomes the nonattractive image that their race has in the Latin nations. This image has made celebrity marketing a very effective form of publicity in the Latin countries [Moreno \& Blanco, 2005, pp.2-4].

Very accomplished dark-skinned Latin athletes who play in their own countries do not have this aura of sophistication; consequently, they do not endorse products. This is very easy to see in Mexico where most of the best soccer players, and the few world-class boxers and long distance runners the country has had in the recent past do not endorse any products. Simply, their features are too Indian.

The third exception to the rule of exclusive use of models of European appearance happens when governments need to communicate a message of social interest. These messages could be as varied as inviting the public to reduce the consumption of water and electricity, or asking drivers to behave with civility when they are behind the wheel. Many of the individuals who appear in the T.V. spots and printed ads of these messages have Indian, Mulatto and Mestizo appearances. 
The overt preference for the European appearance has also affected the effectiveness of T.V. commercials and printed ads originally made for the English- speaking Hispanic populations of the U.S.A. These commercials and printed ads, properly translated, have appeared in Latin America to help market the growing supply of American goods in this region. The strategy of using commercials specially developed for the English-speaking Hispanic markets in the U.S.A, although apparently sound, has not worked well, as the few firms that have tried it have found out. T.V. commercials and printed ads made for the English-speaking Hispanic populations of the U.S.A. tend to include Mestizos, Mulattos, blacks and even Indians, which violates the non-written rule that in Latin America, only European looking models should be used. The exception to this rule, as noted above, is when the dark-skinned individuals appearing in the ads or commercials are accomplished athletes who play in Europe or in the U.S.A.

Latin America's resilient racial caste system has also affected promotion activities such as expositions, fairs and presentations of new products. In these events, if the product is sophisticated or supposed to be sophisticated, not only the models are expected to have a European appearance, but the hostesses are also expected to have this appearance. In the nations where the dark-skinned are the majority, this practice constitutes a problem for the firms organizing the expositions or presentations of new products, for there are very few young white women who are willing to work as hostesses and even less that have the need to do this type of work. In some countries, like Mexico, the firms that organize this kind of event have solved this problem by hiring as hostesses American, European and Argentinean young women who were living in Mexico [Moore, 1998, pp. 71-72].

\section{EFFECTS OF THE CASTE SYSTEM ON PRICE, PRODUCT AND PLACE.}

Luxury consumer goods in Latin America have higher prices than in the USA. Often, these goods are even pricier in the Latin nations than in Europe. Traditionally, these steep prices have been attributed to high sale taxes, which could reach $30 \%$, and to the oligopolistic and monopolistic organization of the retail sectors [Bulmer-Thomas, 2003, pp.403-409]. There is, however, an extra cause for the high prices of luxury goods such as imported processed

foods, most cosmetic products, designer clothing and sophisticated electronics: the strong status orientation of affluent Latin American consumers, i.e., the extra high prices of luxury goods in Latin America is, at least in part, the result of the consumers' desire to show, through the purchasing of these goods, that they belong to the privileged classes [Zimmerman, 2002, pp. 7-11].

In the nations where the dark-skinned are the majority, the strong status orientation of consumers is augmented by the racist attitudes of whites and racially mixed individuals who pass as whites. As mentioned above, there is a marked racial pecking order in these nations. The whites are at the top, the Mestizos and Mulattos are in the middle, and the Indians and blacks are in the bottom rung. Hence, in the nations where the majority is darkskinned, the extra high prices of luxury goods are tolerated because they help whites, and light skinned Mestizos and Mulattos to reiterate their racial superiority.

The low standing of the dark-skinned does not imply that they never buy luxury goods. Due to demographic changes that are described in section six below, and due to some economic progress in countries like in Mexico, Venezuela, Colombia and other Latin nations there is a growing number of non-white consumers who buy luxury goods. With their purchases, these affluent dark-skinned consumers are showing their tolerance of the extra high prices of luxury consumer goods. This tolerance could be interpreted as part of the cost these consumers are willing to pay to show, through the goods they buy, that they have made it into the upper classes. Nonetheless, buying expensive and exclusive goods does not gain affluent dark-skinned individuals a place in white society. For many whites, a dark-skinned individual does not stop being racially inferior just because he or she is wealthy and can afford expensive goods [Wagley, 1994, p. 25].

There is, of course, a limit to the extra amount that affluent consumers are willing to pay for luxury goods. Determining this limit is a matter of market research. However, these limits will be directly related to the level of affluence of each country, and to the real or perceived level of sophistication of each luxury good.

Racial views also affect the product. Latin American manufactured products have a stigma: low quality. Economists attributed this problem to the excessive protectionism, use of obsolete technologies, and ample 
government intervention in the economy that prevailed in these nations until the early 1990s [Weintraub, 1984, pp.77-91; Mizrahi, 2000, pp. 63-64] Therefore, it would be expected that the tariff reductions and economic deregulations that have occurred throughout this region during the last 15 years should have significantly reduced this stigma. Nonetheless, as the example of Mexico shows, the stigma continues.

In 1994 Mexico began the implementation of the North American Free Trade Agreement, the NAFTA. In that year Mexico exported $\$ 51$ billion of manufactured goods. By 2007 Mexico's exports of manufactures reached $\$ 271.9$ billion and generated at least 20\% of the GDP [Banco de Mexico, 2008]. Thus in a period of 13 years Mexico's exports grew a total of $433 \%$. This performance suggests that Mexican products, or at least products assembled in Mexico, are not consistently of poor quality. Nonetheless, for many Mexican consumers, especially for those who are affluent, Mexican products have been and continued to be shoddy because Mexican workers are inferior.

For Latin American producers of manufactured goods the problem with the low quality stigma is not whether it is valid or invalid; but rather, that it gives American, European, and Japanese products, especially luxury products, a competitive edge. This edge cannot be taken lightly because, with the exception of Venezuela, Argentina and Cuba, the other Latin American countries are likely to continue opening their economies.

One tactic that could help Latin American producers of luxury goods with the stigma of low quality, is to link their products to technology or inputs from the USA, Europe or Japan. This link might be legitimate or just an advertising gimic; but whatever the case, by communicating this connection to consumers, Latin American producers would improve the image of their products.

Place or distribution, the last element of the marketing mix, is probably the least affected by the resilient racial caste system. Throughout the Latin nations the distribution of goods and stores follows the geographical distribution of wealth. Thus, stores that only sell normal and inexpensive goods are found in the areas where the poor and working classes live, areas where the clientele is almost exclusively dark-skinned. High quality and luxury goods are sold in stores and department stores located in wealthy neighborhoods. The clientele of the stores located in wealthy neighborhoods is not, however, exclusively formed by whites and fair-skinned Mestizos and Mulattos. These stores are selling to a growing number of dark-skinned consumers. These consumers live in low income and working class areas, but due to demographic changes that are described later in section six and due to the economic progress achieved in recent years, some of them have the income to occasionally buy high quality and luxury goods. Thus, selling through high end stores does not mean excluding potential dark-skinned buyers. On the other hand, selling exclusively through stores that sell only inexpensive and normal goods precludes selling to the whites and racially mixed individuals who think of themselves as whites. This happens because the whites, Mestizos and Mulattos who consider themselves members of the upper classes, very rarely shop in stores that sell to the poor and working classes. Doing this is identifying oneself, at least temporarily, with the lower classes, and hence, with the Indian or African races.

Marketers must be aware that products introduced to Latin American markets through stores that serve the poor and working classes, will be identified as goods purchased by the dark-skinned consumers. Once this identification takes place, it will be very difficult to introduce these products into the stores that serve the upper classes.

\section{HISPANIC EXECUTIVES NOT WANTED}

Most Latin American countries have adopted, since the mid 1990s, the so called Neoliberal model. The main policies of this model are: emphasis on property rights, reduction of trade barriers, deregulation of domestic markets, pursuit of fiscal and monetary discipline, establishment of competitive exchange rates, privatization of many government owned companies, and reduction of the role of government in the economy [Kay, 2003, p.19]. That is, this model tries to promote growth by promoting the formation of free markets. 
The openness and economic stability brought about by the adoption of the Neoliberal model have attracted and will continue to attract a growing number of non-Latin American firms to Latin America. To start serving the markets in the Latin countries, the non-Latin American firms have to select entry strategies such as franchises, alliances with domestic firms or the establishment of subsidiaries. Regardless of the entrance strategy chosen, the non-Latin American firms have to send executives to Latin America to implement, at least partially, the selected entry strategy. Besides their normal work, these non-Latin executives have the extra task of bridging the cultural gap between their firms and the society of the nation where they were sent. For some non-Latin firms, especially for American firms, selecting Hispanic executives for these jobs appears to be quite adequate. Hispanics, especially those whose parents were immigrants strongly identify with the Latin culture and tend to be fluent in Spanish. Unfortunately, Hispanic executives tend not be welcomed.

As mentioned above, wealth in Latin America is highly concentrated in the hands of whites. Hence, nonLatin executives sent to Latin America to implement entry strategies deal directly with Latin American whites. Latin American whites, in general, do not welcome Hispanic executives because, racially, Hispanics tend to be Mestizo, Mulatto or Indian. Hence, for most Latin American whites, these Hispanic executives owe their economic progress to the migration of their parents to the U.S.A., but they are still racially inferior. Furthermore, some Latin American whites may even resent their non-Latin partners for sending a Hispanic executive rather than a white executive.

The antipathy that Latin American whites feel towards dark-skinned Hispanics has been shown by the Cuban community in the U.S.A. The overwhelming majority of Cubans and their descendants in the U.S.A. are white. Members of this community have openly stated that while culturally and linguistically they have ties to the Hispanic segment of American society, they are inherently superior to this segment of American society [Davila, 2000, p.19].

Besides the antipathy that many Latin American whites feel towards the dark-skinned Hispanics, there is another reason for not sending dark-skinned Hispanic executives to Latin America. Indian, Mestizo, and Mulatto Hispanics tend to have a very rosy view of Latin America's racial reality. They tend to see the Latin societies as racial democracies, free of any kind of racial prejudices. Thus, when they run across the racial prejudices of the white segments of the Latin American societies, they are confused and often saddened, which undermines their effectiveness in their assignments.

\section{LONG TERM PERSPECTIVES}

The adoption of the Neoliberal model began, as mentioned above, in the early 1990s. The free market policies of this model have yet to produce sustained economic growth and economic equality [Vilan, 2006, pp. 1821]. Hence, the continuation of the racial caste system is assured. This assurance does not, however, mean that the markets for consumer goods throughout Latin America are likely to stagnate.

There are 537 million inhabitants in Latin America Of this total, 88 percent live in nations where the darkskinned are the majority. In these nations a little more than one fourth of the population is under the age of 15 years and the median age is below 25 years [CIA, 2008].. This means that currently, and for the next two decades, the consumer markets of the Latin nations where most consumers are dark-skinned will receive large numbers of newcomers.

Most of these newcomers are, and will continue to be, poor by the standards of the developed nations. Nonetheless, the purchasing power of these new entrants is, and will continue to be, significantly larger than what is indicated by aggregate figures, such as income per head. This is suggested by the demographic changes occurring in the Latin American households and by the remittances that the poor of several Latin nations receive.

In 2007 the number of children per woman in the countries where the dark-skinned are the majority was between 3.8, in Paraguay, and 1.88, in Brazil [CIA, 2008]. These numbers, while high in comparison to the developed world, are quite low next to what they used to be a couple of decades ago in most Latin nations. An implication of this decline is that women are joining the organized labor force. This combined with the fact that, in 
all social classes, the children stay in the household of the parents until they marry implies that in a growing number of Latin American households there are, or soon there will be, at least two wage earners. The increase in the number of wage earners combined with the decline in the number of children per woman means that the Latin households will spend less in basic necessities, and consequently, will have more disposable income to spend in luxury goods [Zimmerman, 2002, pp. 7-11].

Adding to the disposable income of the poor and working classes are the remittances sent by Latin Americans working, legally and illegally, in the U.S.A. Practically all of the remittances sent to Latin America, which in 2005 reached $\$ 49.2$ billion, go to countries where the dark-skinned are the majority [CEPAL, 2006, p.140]. At the aggregate level this figure does not seem very relevant, since it represented 3\% of the GDP of Latin America in that year. The remittances become very relevant, however, when the effect that they have on the income of the poor is measured. The great majority of the five to seven million households that currently receive remittances are, as mentioned above, poor and working class households. The annual average income, without remittances, of these households is, at most, $\$ 5,000$. In 2002, the remittances added an extra $\$ 2,500$ to this figure [CEPAL, 2006 and Cañas, Coronado \& Orrenius, 2007, pp.3-7]. That is, the remittances increase the income of the households that receive them by $50 \%$.

Currently as result of the recession in the USA and of the stern enforcement of immigration laws, the remittances are declining. Given, however, the large and expanding demand for cheap labor in the USA, the remittances to Latin America are likely to return to their path of growth of $14 \%$ to $20 \%$ per year.

\section{CONCLUSIONS}

Latin America's racial caste system has been quite resilient. It endured the political transformations brought about by independence and the rapid economic growth experienced during the period known as the Export-led era (1850- 1945). It became fuzzy during the times of the Import Substitution Industrialization model, when stern protectionism flourished and the Latin economies developed their industrial sectors (1945 to early 1980s). It has survived the Neoliberal model (mid 1990s to the present), because despite its free market orientation, this model has failed to transform the business environment of Latin America, from its present and historical aristocratic organization into a meritocracy. Therefore, the racial caste system is not likely to disappear in the foreseeable future.

As long as the racial caste system continues, the overt preference for the European appearance will also persist. Hence, only models of European appearance should appear in T.V. and internet commercials and printed ads. Also as long as the business organization continues to have its aristocratic form, the racist convictions of white and individuals who pass as whites will persist, which means that the racial ego of affluent consumers will continue to allow the inclusion of an extra charge in the price of luxury goods. For Latin American producers of high end goods, however, the continued presence of the racial caste system means that they will have to maintain their struggle with the stigma of poor quality that has accompanied Latin American manufactured products.

The resilient racial caste system will continue to create fussy divisions among consumers. It will be, however, erroneous to infer that these fussy divisions will preclude the expansion of the demand for all kinds of goods in the countries where Mestizos, Indians, blacks and Mulattos are the majority. These demands will continue expanding because the number of wage earners per household is increasing and the remittances that they receive from the USA, although currently stagnated, are likely to start growing once the American economy resumes its normal rate of expansion.

\section{AUTHOR INFORMATION}

Rutilio Martinez is an associate professor of statistics at the Monfort College of Business of the University of Northern Colorado. He has taught at this school for 14 years. From 2000 to 2005 he was a partner of CG Americas, a Denver firm that promoted businesses between the USA and Mexico. He teaches a lass about Latin American business culture and economics in Furtwagen University in Germany. He has a Ph. D. in economics from Vanderbilt University. 
Vish Iyer has been teaching marketing classes at the Monfort College of Business of the University of Northern Colorado for more than 20 years. He has more than 30 publications in peer reviewed journals. He has a Ph. $\mathrm{D}$. in marketing form the University of Texas A\&M. During his career at the Monfort College of Business, he has received several teaching awards

\section{REFERENCES}

1. Banco de Mexico. Cuenta Corriente. Retrieved June 30, 2008, from www.banxico.org.mx

2. Bulmer-Thomas, V. (2003). The Economic History of Latin America Since Independence. New York, NY: Cambridge University Press.

3. Cañas, J., Coronado, R., \& Orrenius, P. (2007, July/August). Explaining the Increase in Remittances to Mexico. Southwest Economy. Federal Reserve Bank of Dallas.

4. CEPAL (2006). Anuario Estadístico de América Latina y el Cribe, 2006. Washington, DC: Comisión Económica para América Latina y el Caribe.

5. CIA. (2008).The World Factbook. Retrieved April 2 and 3, 2008, from www.cia.gov.

6. Davila, F. (2000, June).Nothing in Common. Hispanic Business.

7. Derossi, F. (1971). The Mexican Entrepreneur. Paris, France: Development Centre Studies of the Organisation for Economic Co-operation and Development.

8. Graham, R. (1990). The Idea of Race in Latin America, 1870-1940. Austin, TX: University of Texas Press.

9. Hely, A. (1990). Race in Argentina and Cuba, 1880-1930: Theory, Policies and Popular Reaction. In R. Graham (Ed.), The Idea of Race in Latin America, 1870-1940. Austin, TX: The University of Texas Press.

10. Herring, H. (1968). A History of Latin America from the Beginnings to the Present. Third Edition. Mew York, NY: Alfred P. Knopf.

11. Jordan, M. (2000, November 11). Marketers discover black Brazil. Wall Street Journal, p. A2.

12. Kay, S. (2003, Third Quarter). Putting Second-Generation Reforms to the Test. EconSouth. Federal Reserve Bank of Atlanta.

13. Knight, A. (1990). Racism, Revolution and Indigenismo: Mexico, 1910-1940. In R. Graham (Ed.), The Idea of Race in Latin America, 1870-1940. Austin, TX: The University of Texas Press.

14. Monsivais, C. (2005, May 22). Racismo alrevés es "Nunca lo dije." Proceso. México D.F.: Comunicación e Información, S.A. de C.V. No. 1490, pp. 32-34.

15. Moreno, R., \& Blanco, M. (2005). El Celebrity Marketing como Estrategia de Marcas. Unpublished paper. Puebla, Pue.: Departamento de Mercadotecnia, Universidad de las Americas.

16. Mizrahi, T. (2000, June).Tying up the Market. MB The Magazine of the NAFTA Market Place.

17. Nevaer, L. (1995). Strategies for Business in Mexico. Free Trade and the Emergence of North America, Inc. Westport, CT: Quorum Books.

18. Patrinos, H., \& Hall, G. (2005). Indigenous Peoples, Poverty and Human Development in Latin America: 1994-2004. Washington, D.C.: The World Bank

19. Skidmore, T. E. (1990). Racial Ideas and Social Policy in Brazil 1870-1940. In Graham, R., (Ed.), The Idea of Race in Latin America (pp. 27-28) Austin, TX: University of Texas Press.

20. Stavengahen, R. (1994). Challenging the Nation State in Latin America. In J. Dominguez, (Ed.), Essays on Mexico, Central and South America. New York, NY: Garland

21. The Economist (1994, November 26). A Survey of Argentina. The Economist, p.18.

22. Vilan, D. (2006, Second Quarter). Financial Volatility and Electoral Uncertainty in Latin America: Perspectives for 2006. EconSouth. Federal Reserve Bank of Atlanta.

23. Wagley, C. (1994). On the Concept of Social Race in the Americas. . In J. Dominguez, (Ed.), Essays on Mexico, Central and South America. New York, NY: Garland

24. Weintraub, S. (1984). Trade between Mexico and the United States? Washington D.C.: The Brookings Institution.

25. Wright, W.R. (1990). Café con Leche. Race, Class, and National Image in Venezuela. Austin, TX: University of Texas Press.

26. Zimmerman, T. (2002). Selling High-Quality Consumer Goods to Mexico. Zurich: Latin American Chamber of Commerce in Switzerland. 